\title{
Power of the law, power to the people: pursuing innovative legal strategies in human rights advocacy
}

\author{
Tanja Venisnik ${ }^{1}$
}

The use of legal tools and mechanisms in human rights advocacy can play a significant role in the advancement of human rights. Although often difficult, complex and time-consuming, using legal strategies, particularly strategic litigation, in campaigning and advocacy can influence decision-making processes and bring actual changes in legislation, policy and practice. It can also help raise public awareness about a particular human rights issue and empower communities to claim their rights by involving them in designing and implementing legal advocacy strategies.

However, pursuing legal strategies to advance human rights is easier in some jurisdictions than in others. In countries where political space for human rights advocacy is limited and the rule of law weak, relying on human rights norms tends to be inefficient and can even prove counter-productive. In these cases, invoking other legal norms, such as environmental protection laws, can prove more useful for the improvement of the human rights situation on the ground.

\section{Struggles of communities affected by large-scale development projects}

In this respect, working on human rights issues in South East Asia (SEA) presents a particular challenge. There is a lack of openness to human rights discourse, and the implementation of human rights norms is weak, even if those norms are in fact a part of domestic law. ${ }^{2}$ The inexistence of an effective

1 The views expressed by the author in this chapter are her own and are not necessarily endorsed by the organisation for which she works.

2 Most SEA countries have ratified core human rights treaties, such as the International Covenant on Civil and Political Rights (ICCPR) and the International Covenant on Economic, Social and Cultural Rights (ICESCR). However, none of the SEA countries have ratified the optional protocols establishing and providing access to complaints mechanisms under these two treaties. The only exception is the 
regional human rights mechanism amplifies these challenges. ${ }^{3}$ In these contexts where the judiciary lacks independence and is painstakingly inefficient, access to justice for human rights and environmental violations is often difficult.

Another element that poses further obstacles to the realisation of human rights in the SEA region is poorly regulated cross-border investment. As ASEAN is developing its Post-2015 agenda and moving towards regional economic integration, cross-border investments in the region will continue to intensify, especially investments from more developed countries in Asia towards less developed. These investments can bring numerous benefits to host countries, however, experience shows that large-scale development projects, such as hydropower dams, mines, agricultural plantations and coal power plants, bring significant risks to the environment and human rights, especially when implemented in countries with unstable economies and weak legal regimes, most notably in Lower Mekong countries such as Cambodia, Laos and Myanmar.

The pattern of dispossession is staggeringly clear: in the name of economic development, local communities who mostly rely on fishing and small-scale farming for their livelihoods face loss of land and other natural resources, degradation of the environment, loss of livelihoods and impoverishment. They see no or very little economic benefits for themselves and are forced to leave their homes and traditional livelihoods behind, further worsening their economic situation. Environmental degradation caused by such development projects, such as $\mathrm{CO}_{2}$ emissions and water pollution, and the depletion of natural resources provoke displacement and violent conflict and can have negative implications, both direct and indirect, for the effective enjoyment of human rights. ${ }^{4}$ Despite these recognised threats, many development projects in SEA are going ahead without enough attention to their environmental impacts (local as well as transboundary) and mitigation measures, prior community consultations or transparency and corporate accountability. As the frameworks for understanding and establishing extra-territorial obligations of states and corporate entities have only recently started to develop, communities lack legal remedies and avenues to express their concerns and have their grievances heard and addressed.

Philippines that ratified the first Optional Protocol to the ICCPR.

3 The member states of the Association of Southeast Asian Nations (ASEAN) adopted the Human Rights Declaration and established the ASEAN Intergovernmental Commission on Human Rights (AICHR), however, the Declaration is weak and not legally binding, whereas the AICHR remains a toothless body with no mandate to receive and investigate individual human rights complaints.

4 UN Human Rights Council, Analytical study on the relationship between human rights and the environment, Report of the United Nations High Commissioner for Human Rights, UN Doc. H/HRC/19/34 (16 December 2011). 
Addressing environmental concerns plays an important role in addressing human rights issues and obtaining remedies for negative human rights impacts of environmentally unsustainable development projects. Despite notoriously weak implementation of laws in the Mekong region, lawyers, activists and communities are increasingly using environmental protection laws in order to support broader human rights advocacy efforts. For example, environmental impact assessment laws have been used to demand public participation in decision-making processes around development projects, whereas land laws have been invoked to address land grabs and protect indigenous peoples' rights.

\section{In pursuit of meaningful remedies}

However, seeking remedies in countries where violations occur is often simply not feasible nor effective due to lack of legal mechanisms, weak governmentcontrolled judiciary and prominent vested interests, leaving project affected communities with no meaningful remedy.

In recent years, communities, activists and lawyers in the Mekong region have increasingly been using innovative legal strategies. They have been able to successfully turn to national human rights institutions (NHRIs) to seek redress for human rights abuses stemming from large development projects posing threats to local people and their environment. This especially relates to transboundary cases, such as the well documented Koh Kong Sugar Plantation Case in Cambodia. In 2006, hundreds of villagers in Sre Ambel district had their lands illegally confiscated and were evicted to make way for a large sugar plantation, operated by politically-connected Cambodian companies and controlled by Thailand-based Khon Kaen Sugar Ltd. (KSL). ${ }^{5}$ Unable to obtain remedies in Cambodia, local communities filed a complaint to the National Human Rights Commission of Thailand (NHRCT) against KSL. In its recent final report in the case, the NHRCT invoked the UN Guiding Principles on Business and Human Rights and found that KSL was responsible for human rights violations against the affected communities through the business operations of its Cambodian subsidiaries and that the land grab was in violation of the right to life, the right to self-determination, including the right to manage and benefit from natural resources, and the right to development. Although NHRCT cannot issue binding decisions and can only make recommendations, its findings are nevertheless important for the overall campaign ${ }^{6}$ and can also

5 KSL had an exclusive sales contract with Tate \& Lyle Sugars (T\&L) in the United Kingdom.

6 Koh Kong case is part of a global Clean Sugar Campaign that developed in response to rampant land grabs in Cambodia and serious human rights abuses and environmental damage caused by the Cambodian sugar industry. For more information about the campaign and the case, see Inclusive Development International, Cambodia Clean Sugar Campaign, available at http://www.inclusivedevelopment.net/sugar/ 
be used to support community claims in their litigation against T\&L in the United Kingdom. ${ }^{7}$

Another example comes from Malaysia. In 2014, Cambodian and Thai communities filed a complaint to the Malaysian Human Rights Commission (SUHAKAM) against a Malaysian project developer, Mega First Corporation Berhad, building a hydropower dam in Laos (Earth Rights International 2014). Due to lack of political space and democratic institutions and legal mechanisms to address the issue in Laos the affected communities turned to a Malaysian institution. The communities claimed that if built, this dam, would very likely cause irreversible harm to regional fisheries in the Lower Mekong Basin, seriously affecting the lives, livelihoods and health of millions of people in Laos, Cambodia, Thailand and Vietnam. Yet the project developer did not study the transboundary impacts of the project or provide sufficient information about its impacts. It also failed to provide a meaningful opportunity to affected communities in Laos, Cambodia, Vietnam and Thailand to have their voices heard and to express their concerns about the project.

SUHAKAM initially accepted the complaint and conducted separate hearings with Mega First but ultimately concluded that it had no mandate to address a transboundary issue and therefore could not proceed further with the inquiry. It did, however, make recommendations to the Malaysian government to develop policies to monitor Malaysian companies operating abroad in order to ensure compliance with international human rights standards and adhere to the OECD Guidelines for Multinational Enterprises and establish a National Contact Point (NCP) complaints mechanism.

SUHAKAM's inability to conduct an inquiry into a transboundary case highlights legal difficulties of pursuing transboundary legal cases and the need to strengthen NHRIs and create an independent and functional regional human rights mechanism with a strong mandate. Despite the outcome, solely

(accessed 8 Oct. 2015); and Earth Rights International, Case Study: Koh Kong Sugar, available at http://www.earthrights.org/multimedia/video/case-study-kohkong-sugar (accessed 8 Oct. 2015).

7 In 2013, the affected community filed a law suit in UK courts seeking compensation from T\&L, arguing that under Cambodian law, the land and produce belonged to the Cambodian community and that T\&L wrongly took the sugar cane and so must compensate the community for the stolen sugar. By following the money, the affected community was also able to use the Organisation for Economic Cooperation and Development's (OECD) Guidelines complaint mechanism and file a case with the US National Contact Point (NCP) against American Sugar Refineries (ASR), as owner of T\&L, for its purchase of all of the sugar from the Koh Kong economic land concession. ASR withdrew from the mediation proceedings following the filing of litigation against T\&L. Nevertheless, the US NCP called ASR to conduct a corporate human rights policy review process, a statement which was useful for other advocacy and campaigning efforts. 
by filing the complaint as part of a broader campaign against this particular project as well as against the planned cascade of eleven Mekong mainstream dams, the communities were able to raise awareness about the environmental and human rights issues of the project and harness international support for their plight.

Unfortunately, even positive decisions by quasi-judicial bodies or even legally binding judicial decisions do not necessarily translate into the implementation of human rights due to the absence of enforcement mechanisms. National and international judicial and quasi-judicial bodies can render numerous landmark decisions against states, upholding international or regional human rights standards. However, if they are not enforced by states due to economic reasons and capital pressures, human rights violations cannot be properly addressed and remedied. One example comes from a region that has put in place a regional human rights body that can issue binding legal decisions. In its landmark 2010 decision in the case of the Endorois indigenous community v. Kenya, the African Commission on Human and Peoples' Rights (ACHPR) set a critical precedent that indigenous populations in Africa are legally entitled to collective ownership of their ancestral lands. Despite intensive lobbying from the Endorois community and NGOs and recent positive developments reflected in the creation of a government task force charged with addressing restitution of the lands to the Endorois, compensation for losses due to their eviction, and a benefit-sharing agreement, the implementation has been slow and more has to be done to achieve full and direct implementation of the ruling (Minority Rights Group International 2010; 2014).

These difficulties with enforcement highlight that relying solely on the law or litigation is evidently not enough but it can help lead to positive results, if combined with other advocacy strategies and pressure tools.

\section{Law as a tool for building people's power}

As with any advocacy efforts, lawyers and advocates, especially Western organisations operating in developing countries, should be very careful to make sure that they truly represent the 'asks' of the community and that they do not employ strategies that they think will benefit them. Obtaining the affected community's support and informed consent, based on consultation and community input, is crucial. To that end, victims of human rights and environmental abuses need to be educated about their legal rights and legal and advocacy options that they can use to advance their demands. Engagement with affected communities is indispensable for designing as well implementing legal advocacy strategies, making sure that they are the ones driving the process and linking legal strategies with grassroots campaigning.

The pursuit of legal strategies in human rights advocacy is more than filing lawsuits, complaints and petitions. It is first and foremost raising awareness 
of legal rights and building capacity of communities to understand decisionmaking processes, legal frameworks and legal avenues they can pursue to seek redress and protects their rights. Working closely with the affected communities on a legal case can lead to community empowerment as the process brings together the power of the law and the power of the people and provides an opportunity to create people's movements. Legal advocacy and strategic litigation efforts play into larger campaigning actions. Their ultimate aim lies beyond winning a particular legal case; it is about building people's power and helping create more equitable societies.

\section{Bibliography}

EarthRights International (2014) No Fish, No Food: NGO Coalition Files Complaint Against Don Sahong Dam Developer (20 October 2014), available at http://www.earthrights.org/media/no-fish-no-food-ngocoalition-files-complaint-against-don-sahong-dam-developer (accessed 8 Oct. 2015).

EarthRights International, n.d. Case Study: Koh Kong Sugar, available at http://www.earthrights.org/multimedia/video/case-study-koh-kong-sugar (accessed 8 Oct. 2015).

Inclusive Development International, Cambodia Clean Sugar Campaign, available at http://www.inclusivedevelopment.net/sugar/ (accessed 8 Oct. 2015).

Minority Rights Group International (2014) Kenyan Task Force formed to implement the 2010 Endorois ruling, Press Release (29 September 2014), available at http://minorityrights.org/2014/09/29/kenyan-task-forceformed-to-implement-the-2010-endorois-ruling/ (accessed 8 Oct. 2015).

Minority Rights Group International (2010) Landmark decision rules Kenya's removal of indigenous people from ancestral land illegal, Press Release (4 February 2010), available at http://minorityrights.org/2010/02/04/ landmark-decision-rules-kenyas-removal-of-indigenous-people-fromancestral-land-illegal/ (accessed 8 Oct. 2015).

UN Human Rights Council (2011) Analytical study on the relationship between human rights and the environment, Report of the United Nations High Commissioner for Human Rights, UN Doc. H/HRC/19/34 (16 Dec. 2011). 